\title{
Rompendo Barreiras Educacionais: Negros no Ensino Superior
}

\author{
ANDRÉ AUGUSTO BRANDÃO ${ }^{l}$
}

\section{TEIXEIRA, Moema de P. \\ Negros na universidade: identidade e trajetórias de ascensão social no Rio de Janeiro. Rio de Janeiro: Pallas, 2003.}

O pioneiro nos estudos sobre os processos de ascensão social da população negra brasileira é Thales de Azevedo, que, em 1953, publicou o seu Les élites de couleur dans une ville brésilienne (Paris, UNESCO). Tomando a cidade de Salvador como alvo, Thales de Azevedo mostrou que os indivíduos "de cor" em geral ascendiam socialmente pela via da educação.

Sabemos hoje, através dos mais recentes estudos sobre mobilidade social no Brasil, que a escolarização, sobretudo a superior, continua sendo importante "gargalo" para a ascensão social entre nós. No entanto, sabemos também que para além da baixa cobertura que o ensino superior fornece, principalmente no que tange às universidades públicas, os negros são ainda menos presentes nesse nível de escolarização do que os brancos. Dados da Pesquisa Nacional por Amostra de Domicílios (PNAD) do IBGE, produzidos em 1999, mostraram que o ingresso no ensino superior era alcançado por somente $7,1 \%$ dos brasileiros entre 18 e 25 anos; porém, entre os brancos nesta faixa de idade, o acesso à universidade chegava a $11,2 \%$, enquanto entre os negros não passava de $2,3 \%$.

Longe de tentar explicar o que condiciona essas diferenças, o livro Negros na universidade: identidade e trajetórias de ascensão social no Rio de Janeiro, de Moema de Poli Teixeira, persegue exatamente a questão relativa às estratégias individuais para a mobilidade ascendente, procurando compreender como alunos e professores negros, em sua imensa maioria pobres 
e filhos de pais pouco escolarizados, conseguiram se inserir em uma universidade pública no Rio de Janeiro. Nas palavras da autora, trata-se de identificar as estratégias que possibilitam que alguns poucos negros tenham sucesso onde a imensa maioria falha ou nem mesmo entra no jogo. Para isto, o livro faz um estudo das trajetórias desses indivíduos até sua chegada ao ensino superior (no caso dos alunos) ou à docência universitária (no caso dos professores). Quando e como a pretensão a uma escolaridade superior chega a esses indivíduos? Em que medida tal pretensão pode se relacionar com a determinação de ascender socialmente?

Mas a busca pela compreensão de trajetórias mais pessoais não significou uma abordagem individualizadora. A pesquisa toma essas trajetórias para encontrar sentidos sociológicos e verificar as bases sociais que alicerçam as possibilidades de ascensão educacional e social em meio a diversas barreiras impeditivas. Assim, apesar das quase cem entrevistas realizadas, com alunos e professores das diferentes áreas do conhecimento, são encontradas proximidades importantes entre as estratégias mobilizadas para burlar a discriminação racial e a pobreza.

Produzida originalmente como tese de doutoramento em Antropologia, a obra utiliza-se largamente de expedientes metodológicos qualitativos para empreender um belo mergulho na realidade empírica e ir ao encontro das especificidades que cercaram a vida dos sujeitos estudados. O resultado é uma leitura prazerosa e um texto isento de teorizações excessivas. Mais do que explicar, a autora deixa aqueles homens e mulheres falarem de suas trajetórias e encontra em suas subjetividades a chave para compreender diferenças, identificar regularidades e, só então, dialogar com a teoria.

Há, porém um elemento metodológico que logo chama a atenção do leitor. Na medida em que a universidade pública na qual se realizou o estudo não mantinha qualquer registro de cor ou raça de seus alunos e professores, como fazer para localizar os negros? No caso dos alunos, a autora utilizou as fotografias $3 \times 4$ que constam das fichas de matrícula. No caso dos professores, através de uma listagem nominal de cada departamento de ensino, era solicitado a um funcionário do mesmo que indicasse os não-brancos. $\mathrm{O}$ interessante é que nos dois casos ocorreram percentuais pequenos de discrepância entre a classificação feita pelos funcionários e pela pesquisadora e a autoclassificação dos indivíduos, embora tal percentual acabe sendo um pouco maior no caso dos indivíduos mais miscigenados. 
No capítulo 1 da obra, é realizado um mapeamento por cor ou raça, sem dúvida pioneiro, que comprova o que todos já intuíam "a olho nu": os alunos e professores negros se concentram nas carreiras de menor prestígio e de tendencialmente menor retorno financeiro após a diplomação. O contrário ocorre com os alunos e professores brancos. De fato a pesquisa realizada mostra que os negros estão em maior freqüência nos cursos de ciências humanas e sociais, logo depois na área tecnológica e por último na área biomédica com uma única exceção nesta, relacionada ao curso de enfermagem, em que os negros são muito presentes.

Mas se os negros se encontram sub-representados na universidade enquanto alunos, estão em situação ainda pior enquanto professores. Mesmo em cursos com alta freqüência de negros, os docentes são em imensa maioria brancos. O livro nos fala de um perfil típico desses alunos e professores negros: oriundos de camadas sociais mais pobres e estudantes de escolas de ensino fundamental e médio que possuíam um bom nível de ensino. A escolha mais acentuada por cursos das áreas de ciências humanas é indicada por muitos entrevistados como "realista" frente aos problemas e limitações que enfrentaram em suas histórias de vida como pobres e como negros.

No capítulo 2, a autora discute a identidade racial e encontra a tensão entre dois aspectos identitários: o atribuído e o adquirido. Assim, embora a maioria dos entrevistados aponte e valorize sua origem negra, não necessariamente a "assume" como fundamento de sua identidade. Da mesma forma, alunos e professores negros mostram que não podem "fugir" do seu fenótipo e percebem como os "outros" os olham. Mas nem todos fazem disso um "mote" para sua auto-identificação como negros. Várias das críticas formuladas ao movimento negro caminham nesta direção. Parece não ser bemvinda a idéia de uma uniformização classificatória da identidade racial, daí o fato de que os próprios indivíduos podem atuar dentro de uma margem de manobra que os permite autodeterminar sua identidade de forma não necessariamente holística.

Apesar de tudo isso, são encontradas afirmações de uma identidade negra politizada mesmo entre indivíduos que jamais haviam freqüentado o movimento negro e sequer conheciam suas perspectivas e objetivos. Em linhas gerais, porém, o estudo mostra que a negação da identidade negra não acompanha diretamente os processos de ascensão social, como parece "saber" o senso comum. 
No capítulo 3, o livro aborda a questão da discriminação racial e do preconceito na trajetória de vida desses negros. A autora encontra na fala dos entrevistados os elementos que a permitem construir aportes teóricos para a caracterização de um “jeitinho brasileiro de discriminar”. É como se a fluidez de nossa classificação racial produzisse um alargamento dos campos de possibilidade da discriminação. Assim, a relativa aproximação social entre brancos, negros e mestiços, em momentos de lazer, pode esconder rejeições e afastamentos no trabalho e mesmo na efetivação de laços mais duradouros. Ao contrário da noção tão difundida no senso comum (e mesmo na academia), que afirma que a ascensão social "embranquece" o indivíduo na sociedade, a pesquisa aponta para uma situação na qual mesmo professores com titulação impecável continuam enfrentando o racismo dentro e fora da universidade.

No capítulo 4, são discutidos mais diretamente os projetos e as trajetórias de ascensão social. Para a autora, o elemento fundamental que explica as performances de sucesso que investigou se encontra na possibilidade de formação do que denomina como "rede de solidariedade e ajuda". A referência a essa "rede" aparece em todas as entrevistas realizadas. Destas emana o incentivo para a busca da escolarização superior, mas também nestas se agrupam os recursos materiais e emocionais necessários para a empreitada. Essas "redes" são diferenciadas entre as vidas e os projetos investigados. Assim, pessoas, famílias, instituições, grupos etc. acabam por proporcionar o apoio para a superação de dificuldades relacionadas à condição socioeconômica e aos processos de discriminação racial.

Na conclusão da obra, a autora mostra que foram encontrados inúmeros traços do racismo e da discriminação racial como elementos que condicionaram opções e projetos de formação e de carreira, impactando ainda a forma como esses indivíduos buscam "completar" sua ascensão educacional, profissional e social. Exatamente por isso, a relação entre cor e curso, válida tanto para alunos como para professores, é tão marcante.

A autora sinaliza ainda que, na medida em que somente aqueles que conseguem estabelecer redes de solidariedade chegam ao ensino superior público, aos outros resta a inércia social. Considerando que o estabelecimento dessas bases de apoio deriva de inúmeros aspectos econômicos e sociais e mesmo de várias contingências, podemos pensar que o estabelecimento de "redes" oficiais e públicas produziria uma situação de maior igualdade racial 
no acesso à universidade. Por isso a reflexão sobre a ação afirmativa como política pública se faz hoje tão importante e necessária.

\section{Notas}

${ }^{1}$ Doutor em Ciências Sociais; professor adjunto da Escola de Serviço Social da Universidade Federal Fluminense (ESS/UFF); pesquisador do Programa de Educação dos Negros na Sociedade Brasileira (PENESB/UFF). 